\title{
PERAN BIDAN DALAM PEMBERIAN SUPLEMENTASI TABLET TAMBAH DARAH (TTD) UNTUK PENCEGAHAN ANEMIA IBU HAMIL DI PUSKESMAS II KEMBARAN KABUPATEN BANYUMAS
}

\author{
Alfi Noviyana ${ }^{1}$ \\ ${ }^{1}$ Prodi Kebidanan D3, Fikes, Universitas Muhammadiyah Purwokerto \\ alfinovi13@gmail.com
}

\begin{abstract}
ABSTRAK
Cakupan suplementasi Tablet besi sebenarnya belum tentu menggambarkan keberhasilan program apabila dilihat dari masih tingginya angka anemia saat ini. Rendahnya kepatuhan ibu hamil dalam mengonsumsi suplemen besi merupakan salah satu penyebab angka prevalensi anemia masih tetap tinggi. Begitupula yang terjadi di Wilayah kerja Puskesmas II Kembaran. Kepatuhan ibu hamil dapat lebih ditingkatkan apabila bidan mampu memberikan penyuluhan gizi, khususnya tentang manfaat tablet besi dan kesehatan ibu hamil. Tujuan dari penelitian ini adalah menganalisis sejauh mana peran bidan dalam upaya pencegahan anemia. Desain penelitian ini menggunakan metode kualitatif dengan pendekatan studi kasus. Penentuan informan dilakukan dengan Purposive Sampling. Pengambilan data dilakukan dengan wawancara mendalam, observasi lapangan dan telaah dokumen. Hasil Penelitian ini Bidan telah memberikan pendidikan kesehatan pada ibu hamil tentang tablet tambah darah namun belum menggunakan media dan sudah memberikan suplemen tersebut minimal 90 tablet tetapi pengawasan terhadap kepatuhan ibu hamil belum maksimal.Sehingga perlu melibatkan kader kesehatan, keluarga tau orang terdekat dari ibu hamil untuk meningkatkan kepatuhan dan memanfaatkan media buku KIA.
\end{abstract}

Kata Kunci : Anemia , Peran Bidan

\begin{abstract}
ABSTRACK
Supplementary iron tablet coverage does not necessarily reflect the success of the program when viewed from the current high rate of anemia. The low compliance of pregnant women in consuming iron supplements is one of the causes of the prevalence of anemia is still high. It occurs in the working area of Health Center II Kembaran. Compliance with pregnant women can be further improved if the midwife is able to provide nutrition counseling, especially about the benefits of iron tablets and the health of pregnant women. The purpose of this study is to analyze the extent of the role of midwives in efforts to prevent anemia. The design of this study uses qualitative methods with a case study approach. Determination of informants is done by Purposive Sampling. Data collection is done by in-depth interviews, field observations and document review. The results of this study Midwives have provided health education to pregnant women about tablets plus blood (TTD or iron tablet) but have not used the media and have given these supplements a minimum of 90 tablets but supervision of the compliance of pregnant women has not been maximized. So it needs to involve health cadres, families know the closest people to pregnant women improve compliance and utilize KIA book media.
\end{abstract}

keywords:Anemia, the role of midwives 


\section{PENDAHULUAN}

Pemerintah masih menilai keberhasilan program suplementasi $\mathrm{Fe}$ (TTD) dengan indikator cakupan distribusi suplemen besi. Namun, cakupan suplementasi TTD sebenarnya belum tentu menggambarkan keberhasilan program apabila dilihat dari masih tingginya angka anemia saat ini. Efektifitas dari program suplemetasi Fe di kabupaten Banyumas untuk ibu hamil tergantung pada kebijakan, pendanaan yang mendukung ketersedian $\mathrm{Fe}$ agar program berjalan sebagaimana semestinya (Purwati, 2016).

Selain ketersediaan TTD dan akses terhadap pelayanan, ada hal lainnya yang dapat memengaruhi keefektifan program suplementasi besi yaitu dari sisi penyedia layanan, yang berupa kualitas konseling tentang suplemen besi, serta dari sisi ibu hamil yaitu kemauan ibu untuk mengonsumsi suplemen besi (Yuni, dkk, 2015), Kepatuhan ibu hamil dapat lebih ditingkatkan apabila bidan desa mampu memberikan penyuluhan gizi, khususnya tentang manfaat tablet besi dan kesehatan ibu hamil. Tenaga kesehatan yang terlibat dalam program suplementasi TTD khususnya pemantauan kepatuhan adalah tenaga kebidanan dan tenaga gizi (Kemenkes RI, 2015).

Uraian di atas menjadi dasar penelitian ini dilakukan dengan tujuan menganalisis sejauh mana peran bidan sebagai pelaksana pemberian TTD, pemberian pendidikan kesehatan tentang TTD erta pemantauan kepatuhan konsumsi TTD dalam upaya pencegahan anemia.

\section{METODE}

Desain penelitian ini menggunakan metode kualitatif dengan pendekatan studi kasus. Penelitian dilaksanakan di Wilayah Pukesmas II Kembaran, bulan Januari 2018. Penentuan informan dilakukan dengan Purposive Sampling yang terdiri dari informan utama yaitu tenaga kesehatan (bidan) sebanyak 5 bidan desa dan informan pendukung yaitu bidan koordinator dan ibu hamil sebanyak 5 ibu hamil. Pengambilan data dilakukan dengan wawancara mendalam, observasi lapangan dan telaah dokumen. Wawancara menggunakan pedoman wawancara dan dilakukan di Puskesmas. Keabsahan data dilakukan triangulasi metode dan data. Analisis data menggunakan Multiple Case Analisys (Sulaeman, 2015). 


\section{HASIL DAN PEMBAHASAN}

Bidan sebagai tenaga kesehatan mempunyai peran dan fungsi yang penting dalam program-program pemerintah, khususnya pencegahan anemia pada ibu hamil. Permenkes No. 88 tahun 2014 tentang Standar Tablet Tambah Darah bagi Wanita Usia Subur dan Ibu Hamil menjelaskan bahwa pemberian TTD pada ibu hamil dilakukan dengan pemberian minimal 90 tablet selama kehamilan. Bidan sesuai dengan permenkes no 97 tahun 2014 Pemberian TTD oleh bidan sesuai dengan buku panduan program diikuti dengan pemberian pendidikan kesehatan tentang informasi TTD, cara minum, efek samping dan pendidikan kesehatan tentang nutrisi pada ibu hamil.

Bidan sebagai tenaga kesehatan berperan dalam pencegahan anemia pada ibu hamil memberikan pendidikan kesehatan pada setiap kunjungan ibu hamil di PKD (Pos Kesehatan Desa) maupun Puskesmas. Pendidikan kesehatan tersebut adalah cara minum tablet tambah darah, nutrisi yang cukup sebagai pendukung pencegahan anemia, seperti yang dikemukan oleh Informan utama 1:
"Ya diberikan cara minum TTD malam hari kalo mual, diminum rutin setiap hari kalo yang anemia $2 \times 1$ tablet, kalo yang ibu hamil ndak anemia $1 \quad x \quad 1$ tablet, makan yang bergizi, sayur hijau ya gitu”.

Pernyataan tersebut juga di dukung oleh pernyataan Informan Pendukung :

"Ya mengkonsumsi makanannya, apa lagi..kalo konsultasi ya dikasih saran, Biasanya diminum $1 \mathrm{kali}$, diminumnya pagi 1 kali yang malem 1 kali yang penambah darah itu”.

Hasil observasi lapangan semua responden utama memberikan pendidikan kesehatan terkaitan pemberian TTD sebagai pencegahan anemia dan pendidikan kesehatan nutrisi pada ibu hamil. Pendidikan kesehatan dalam kunjungan ulang ANC bersifat mengingatkan kembali ibu hamil untuk minum obat dan memperhatikan makanan yang dikonsumsinya. Kepatuhan ibu hamil dalam mengkonsumsi $\mathrm{Fe}$ dapat ditingkatkan dengan memberikan penyuluhan tentang suplementasi TTD oleh tenaga kesehatan (Rahmawati, 2008). Hal ini sejalan dengan penelitian Yuni,dkk (2015) pentingnya meningkatkan kualitas konseling saat ANC untuk meningkatkan kepatuhan konsumsi 
suplemen besi dalam upaya pencegahan dan penanggulangan anemia pada ibu hamil.

Petugas kesehatan berperan pada tingkat kepatuhan ibu hamil dalam mengkonsumsi tablet Fe (TTD), Petugas kesehatan dapat berperan sebagai komunikator, motivator, fasilitator dan konselor untuk ibu hamil (Lina, 2013). Kepatuhan terhadap konsumsi TTD ibu hamil masih sangat rendah, yang secara umum diakibatkan masih rendahnya pengetahuan mengenai TTD baik mengenai efek samping, penyerapan besi, makanan dan obat yang mengganggu penyerapan zat besi dan mitos serta kepercayaan yang salah (Kemenkes RI, 2015).

Pendidikan kesehatan merupakan salah satu cara untuk memberikan informasi pada orang lain. Pendidikan kesehatan akan lebih efektif jika menggunakan media tertentu sebagai alat untuk memperjelas atau memperagakan sjuatu informasi pada ibu hamil. leaflet atau lembar balik merupakan media yang efektif bagi bidan untuk memberikan pendidikan kesehatan pada ibu hamil. Hasil penelitian didapatkan tidak ada media yang digunakan oleh bidan dalam membrikan pendidikan kesehatan pada ibu hamil, bidan merasa sudah hafal di luar kepala untuk materi tentang pendidikan kesehatan tersebut, seperti hasil wawancara berikut ini:

"Hehehe.. nggak ada mbak, paling pake buku KIA" (Informan Utama 1)

"Ada sebnernya tapi jarang dipake, halah wis di luar kepala" (Informan Utama 2)

"Ada kok medianya, medianya dari Dinas, tapi ya kadang mereka tidak menggunakan media, sudah diluar kepala”. (Informan Pendukung 3)

Hasil observasi lapangan didapatkan bidan tidak menggunakan media dalam memberikan pendidikan kesehatan, bidan hanya menjelaskan secara lisan. Hasil penelitian ini menyimpulkan hampir semua bidan tidak menggunakan media untuk memberikan pendidikan kesehatan, hanya menjelaskan secara lisan walupaun telah tersedia buku KIA sebagai media untuk pendidikan kesehatan. Hal ini sejalan dengan penelitian Sistiarani (2014) bahwa pemanfaatan media dalam sesi pendidikan kesehatan akan mendorong komunikasi yang efktif antara petugas kesehatan dan ibu, hasil penelitian ini juga mengungkapkan bahwa bidan desa di kabupten Banyumas belum 
memaksimalkan buku KIA sebagai media KIE kesehatan ibu.

Hasil telaah dokumen Permenkes no 88 tahun 2014 tentang pemberian TTD menyatakan bahwa pemberian TTD pad ibu hamil adalah 90 tablet selama kehamilan. Hasil wawancara dengan responden dihasilkan bahwa bidan sudah memberikan TTD sejulah 90 tablet, bahkan lebih dari 90 tablet, seperti pernyataan responden berikut ini "Dari awal sampai akhir itu lebih dari 90" (Informan utama 1)

"Minimal ibu hamil 90 tablet tercapai” (Informan utama 3).

Bidan memberikan TTD pada ibu hamil melalui pelayanan ANC baik di PKD dan Puskesmas. Hasil tersebut sesuai dengan hasil observasi bahwa setiap ada ibu hamil melakukan kunjungan ANC di PKD dan Puskesmas diberikan TTD. Hal tersebut didukung dengan hasil wawancara dengen responden sebagai berikut:

"Kita kan melakukan ANC dipuskesmas kemudian meresepi fe, kemudian ibu hamil mengambil obat ke obat bagian Apotik" (Informan utama 2).

"Pas periksa di bidan, eh tapi di puskesmas juga di kasih" (Informan pendukung 1)
Tercapainya angka cakupan Fe1 dan Fe3 di Puskesmas II Kembaran tidak dapat sepenuhnya dijadikan tolok ukur karena angka kejadian anemia masih cukup tinggi. Cakupan Fe hanya menggambarkan jumlah dari tablet $\mathrm{Fe}$ yang sudah diberikan pada ibu hamil tanpa melihat kepatuhan dari ibu hamil. Angka anemia yang cukup tinggi kemungkinan disebabkan ketidakpatuhan konsumsi tablet $\mathrm{Fe}$, ketidakpatuhan disebabkan penge-tahuan ibu hamil yang kurang. Kepatuhan konsumsi tablet $\mathrm{Fe}$ dipengaruhi oleh pengetahuan ibu hamil tentang cara minum, dampak dan manfaat tablet $\mathrm{Fe}$ (Ramawati, dkk., 2008; Mediana, 2004; Noviyana, 2016). Pengetahuan sangat berperan dalam mening-katkan kepatuhan mengkonsumsi tablet besi, sehingga penjelasan tentang tablet besi oleh petugas kesehatan harus dioptimalkan sehingga kepatuhan semakin meningkat. Belum adanya peman-tauan khusus untuk konsumsi TTD juga mempengaruhi kepatuhan ibu hamil (Adianti, dkk., 2015).

Kader kesehatan adalah tenaga yang berasal dari masyarakat yang dipilih oleh masyarakat dan berkerja bersama untuk masyarakat secara 
sukarela (Kemenkes RI, 2012). Kader berperan menjembatani antara ibu hamil dan tenaga kesehatan dalam hal memberikan informasi berkaitan tentang pengaturan kelahiran, pemeriksaan kehamilan, makanan yang sehat pada ibu hamil, menjaga kebersihan diri dan mengenali tandatanda bahaya pada ibu hamil. Purwati (2018) menyatakan bahwa kader memberikan kontribusi dalam konsumsi obat melalui motovasi, dorongan dan memberi informasi pada ibu hamil tentang tata cara minum tablet $\mathrm{Fe}$.

\section{SIMPULAN DAN SARAN}

Bidan telah berperan dalam pencegahan anemia pada ibu hamil yakni memberikan pendidikan kesehatan pada setiap kunjungan ibu hamil di Pos Kesehatan Desa (PKD) maupun Puskesmas tentang cara minum tablet tambah darah, nutrisi yang cukup sebagai pendukung pencegahan anemia namun belum memanfaatkan media pendukung yang telah sediakan dalam memberikan pendidikan kesehatan pada ibu hamil. Bidan juga telah memberikan minimal 90 TTD namun pengawasan kepatuhan ibu hamil dalam mengkonsumsi TTD belum maksimal. Saran perlu melibatkan kader kesehatan dan keluarga atau orang terdekat ibu hamil untuk meningkatkan kepatuhan mengkonsumsi TTD dalam upaya menurunkan angka kejadian anemia pada ibu hamil dan pemanfaatan buku KIA.

\section{DAFTAR PUSTAKA}

Aditianti, Yurista Permanasari, dan Elisa Diana Julianti. 2015. Pendampingan Minum Tablet Tambah Darah (TTD) Dapat Meningkatkan Kepatuhan Konsumsi Ttd Pada Ibu Hamil Anemia.. Penelitian Gizi dan Makanan, Juni Vol. 38 (1): 71-78

Dian Ramawati, Mursiyam, Waluyo Sejati Faktor-Faktor Yang Mempengaruhi Kepatuhan Ibu Hamil Dalam Mengkonsumsi Tablet Besi Di Desa Sokaraja Tengah, Kecamatan Sokaraja, Kabupaten Banyumas. 2008. Jurnal Keperawatan Soedirman (The Soedirman Journal Of Nursing), Vol 3(3)

Dinas Kesehatan Kabupaten Banyumas. (2016). Profil Kesehatan Banyumas 2016. DKK Banyumas

Kemenkes RI, Millenium Challenge Account Indonesia (MCA). (2015). Pedoman Program Pemberian Dan Pemantauan Mutu Tablet Tambah Darah Untuk Ibu Hamil Di Wilayah Program Kesehatan Dan Gizi Berbasis Masyarakat. Jakarta. Kemenkes RI 
.(2014). Peraturan Menteri

Kesehatan Republik Indonesia No 88

Tahun 2014 Standar Tablet Tambah

Darah bagi Wanita Usia Subur dan Ibu hamil. Jakarta. Kemenkes RI

.(2012). Petunjuk Pelaksanaan

Surveilens Gizi. Jakarta. Kemenkes RI

.(2013). Riskesdas 2013. Jakarta.

Kemenkes RI

Lina Handayani. 2013. Peran petugas kesehatan dan Kepatuhan Ibuhamil mengkonsumsi Tablet Besi. Kesmas Vol 7(2) ; 83-88

Mardiana, 2004. Faktor -Faktor Yang Berhubungan Dengan Kepatuhan Ibu Hamil Mengkonsumsi Tablet Besi Di Puskesmas Soko Dan Puskesmas Multi Wahana Kecamatan Soko Kota Palembang, Depok: Tesis FKM

Noviyana, A. 2018. Hubungan Pengetahuan, Sikap dan Perilaku Ibu Ahmil Terhadap Ketidakpatuhan dalam Mengkonsumsi Tablet Tambah Darah di Puskesmas purwokerto Barat Banyumas. Jurnal Kebidanan Harapan Ibu Pekalongan (S.I.), Vol3, (2), p.2, ISSN 2549-2772

Purwaningsih S. (2004). Analisis Faktor - Faktor yang Mempengaruhi Ketidak-patuhan Ibu Hamil dalam Meng-konsumsi Tablet Besi. http://ejournal.undip.ac.id/

index.php/ jnc. Diakses pada tanggal 19 Juni 2018

Purwati, Tamtomo D., Sulaeman E. D. 2016 Context, Input, Process, Product Analysis in the Implementation of Iron Supplementation Program in Banyumas, Central Java. Journal of Health Policy and Management Vol 1(2): 120-127

Purwati, Alfi Noviyana, 2018 Keterlibatan Kader Posyandu Dalam pemantauan Konsumsi Tablet e pada pencegahan Anemia Ibu Hamil di Kabupaten Banyumas. Jurnal Infokes Vol 8 (2); 1-6

Sistiarani colti, Elvira Gamelia, Diah Umiyarni. 2014Fungsi pemanfaatan Buku KIA Terhadap Pengetahuan Ibu dan Anak pada Ibu, Jurnal Kesmas nasional Vol 8 (8):353-358

Sulaeman ES. (2015). Metode Penelitian Kualitatif \& Campuran dalam Kesehatan Masyarakat. Surakarta. UNS Press

Yuni Pradilla, Dodik Briawan, Ikeu Tanzina, Leily Amalia. 2015. Kepatuhan Konsumsi Suplemen Besi dan Pengaruhnya Terhadap Kejadian Anemia Pada Ibu Hamil di Kota Tangerang. Jurnal Gizi dan Pangan. $\begin{array}{lll}\text { Vol } & 10 & \text { (3);171-178 }\end{array}$ 